DOI

http://dx.doi.org/10.1590/2236-463320150912

Neither Wrested nor Granted: Agency,

Structure and the Reasons of the

Brazilian Free Womb Law

\title{
Nem arrancada, nem outorgada: agência, estrutura e os porquês da Lei do Ventre Livre ${ }^{1}$
}

\section{Rodrigo Goyena Soares \\ Doutorando em História Social pela Universidade Federal do Estado do Rio de Janeiro (UNIRIO - Rio de Janeiro-RJ / Brasil). Mestre em História Social pela mesma Universidade e em Relações Internacionais no Instituto de Estudos Políticos de Paris (SciencesPo - Paris / França) e-mail: rodrigo.goyenasoares@ gmail.com}

1

A ortografia portuguesa do século XIX foi atualizada conforme 0 acordo ortográfico de 1990. Agradeço os comentários e as sugestões de Ricardo Salles.

\section{Resumo}

0 artigo procura avaliar em que medida a edição da Lei do Ventre Livre, de 28 de setembro de 1871, constituiu um reflexo da libertação de escravos para combater na Guerra do Paraguai (1864-1870). Buscou-se contrastar, por um lado, a historiografia que analisa a lei emancipacionista como antecipação - e, portanto, como outorga interessada - a eventuais disputas político-partidárias; à leitura, por outro lado, que vislumbra na lei de 1871 o resultado da agência escrava, perpetrada como contágio rebelde entre camadas servis. Ao passo que aquele entendimento parte de uma análise de tipo estrutural, para compreender os porquês da Lei do Ventre Livre, esta assenta-se na agência individual, para explicar alterações estruturais. Dialogando com essas duas perspectivas, o artigo argumenta que antecipações reformistas não operam em desconexão com possibilidades de agência política: mudanças estruturais derivam, portanto, de expectativas constituídas diante de possibilidades de reversão de poder.

\section{Abstract}

The article intends to evaluate to which extend the enactment of the Brazilian Free Womb Law, in the $28^{\text {th }}$ September 1871, derives from the emancipation granted to slaves in order to fight the Paraguayan War (1864-1870). A contrast has been established, on the one hand, between the historiographical literature that understands the emancipationist law as a reform-mongering tactic- and, therefore, as a government grant adopted to avoid possible political disputes; and, on the other hand, the analytical views that perceive the 1871 law as a result of the agency of slaves, understood as rebellious contagion within the slave social layers. While a structural type of analysis underpins the first point of view, the second is embedded within the concept of individual agency in order to understand structural changes. Considering both perspectives, the article argues that reformist anticipations are not disconnected from possibilities of political agency: structural changes, thereafter, derive from expectations constituted when chances of social reversion are at stake.

Palavras-chave

Lei do Ventre Livre, Guerra do Paraguai, agência, estrutura

Keywords

Free Womb Law, Paraguayan War, structure, agency 
"Na guerra do Brasil contra o Paraguai, acaba de ocorrer um evento que será fecundo em resultados. Um decreto do governo brasileiro, que data de 6 de novembro de 1866, concede liberdade aos escravos do Estado que tomarem parte no serviço do Exército: suas mulheres e suas crianças serão também alforriadas" (tradução livre).

3

No original "Et le combat cessa, faute de combatants", CORNEILLE, Pierre (1606-1684). 0 Cid. Paris: Éditions Larousse, 1998. ato 4, cena 3, p.122.

4

RODRIGUES, José Honório (org. e intr.). Atas do Conselho de Estado, Terceiro Conselho de Estado, 1865-1867. Brasilia: Senado Federal. Disponivel em: <http://www.senadofederal.gov.br>. Acesso em: 26 nov. 2013.
Dans la guerre du Brésil contre le Paraguay, il vient de se passer un événement qui sera fécond en résultats. Un décret du gouvernement brésilien, en date du 6 novembre 1866, accorde la liberté aux esclaves de l'État qui prendront du service dans l'armée : leurs femmes et leurs enfants sont aussi affranchis. ${ }^{2}$

[L'Avenir National, 22 de dezembro de 1866]

0 ano de 1866 foi áspero para o Império do Brasil. As tropas brasileiras, em guerra contra o Paraguai desde 1864, mostravam-se exauridas no inconfortável descanso das trincheiras. À dificuldade de recrutamento, oriunda de um patriotismo declinante, em parte devido à insalubridade e à inanição nos postos de comando, somava-se um progressivo retraimento das forças aliadas. Enquanto Bartolomé Mitre, então presidente da Argentina e comandante-em-chefe das tropas aliadas, teria de lidar com levantes separatistas no Norte de seu Estado, fronteiriço com o Paraguai, na banda oriental, o partido Blanco tornava a pôr em xeque a autoridade do partido Colorado, então sob liderança de Venâncio Flores. Pior, em setembro de 1866, as forças aliadas endossaram retumbante derrota em Curupaiti.

Era esse, pelo menos no entender de Mitre e quase plagiando $0 \mathrm{Cid}$ de Corneille, um cenário ideal para cessar a guerra, por falta de combatentes ${ }^{3}$; especificamente, o que Dom Pedro II repugnava. Levar a cabo a derrota de Solano López, então presidente do Paraguai, significava dar fôlego renovado às tropas brasileiras, agora praticamente a sós no conflito. Em outubro de 1866, o Marquês de Caxias foi designado comandante-emchefe das tropas brasileiras, e com ele se formariam os corpos de saúde. Caxias teria de aprimorar o abastecimento das tropas e remediar a eficácia dos combatentes. Ficava pendente, no entanto, a questão do recrutamento. Em convocação extraordinária submetida ao Conselho de Estado, em 1866, Dom Pedro II propunha alforriar escravos para servir nas fileiras de Caxias, não sem antes ter o cuidado de dissociar a premência da guerra, isto é, a crise de recrutamento, da questão servil:

0 gradualismo do processo ou se é imediata a abolição, compulsório ou indenizada, bem como as possiveis fases, com a liberdade dos nascituros ou dos velhos, aumento de recursos para acelerar o emancipacionismo - todas as possibilidade são debatidas. Outro assunto é alforriar escravos para participação nas fileiras do Exército. ${ }^{4}$

A dissociação era certamente um artifício. Não pelo lado da necessidade de avolumar o corpo do Exército e da Armada imperial, mas pelas mudanças estruturais que tal medida acarretaria. Os impactos sociais que desse ato derivariam não seriam magros em consequências. Caso assim não se pensasse, não haveria por que conceder liberdade aos filhos e às esposas dos libertos de guerra, como o fez o decreto 3.725 de 6 de novembro de 1866. Dito de outra forma, alforriar escravos para o serviço do Exército e da Marinha era dar armas, não somente no sentido literal, a um parcela da sociedade que pouco se orgulharia de ter lutado em defesa de um Estado escravocrata.

Estava aí, portanto, o evento fecundo em resultados do qual falava Charles Quentin, autor do artigo publicado em L'Avenir National, que citamos em epígrafe. Na visão do jornalista, seria esse o evento responsável por acelerar o processo da emancipação no Brasil,

autant rapidement que le préjugé de la couleur, si enraciné aux Etats-Unis, est entièrement inconnu au Brésil ; du jour où le noir devient libre, il est absolument 
"Tão rapidamente quanto o preconceito da cor, tão arraigado nos Estados Unidos, é inteiramente desconhecido no Brasil; no dia em que o negro for livre, será absolutamente igual ao branco, não unicamente aos olhos da lei, mas ainda em fatos, poderá aspirar e alcançar as mais altas funções". (tradução livre). L'Avenir National, Paris, 22 de dezembro de 1866. Arquivo Histórico do Museu Imperial. Petrópolis, Rio de Janeiro. Maço 139, doc. 6833 .

6

A expressão é de Fernando Novais e de Rogério Silva, e por esferas de existência designam a economia, a sociedade, a política e a cultura. Ver: NOVAIS, Fernando A.; SILVA, Rogério F. da. Introdução. In:__ (orgs.) Nova história em perspectiva. Vol.1. São Paulo: Cosac Naify, 2011. p.42.

SALLES, Ricardo. Guerra do Paraguai: escravidão e cidadania na formação do Exército. Rio de Janeiro: Paz e Terra, 1990. p.70-75

8

Ver SAHLINS, Marshall. Islands of History. Chicago: University of Chicago Press, 1985 l'égal du blanc, non pas seulement aux yeux de la loi, mais encore en fait, il peut aspirer et parvenir aux plus hautes fonctions. ${ }^{5}$

A poucos causaria surpresa consentirmos com o equívoco analítico de Quentin, mas inclinamo-nos a seu favor quanto aos abalos estruturais que o decreto de 1866 traria. É precisamente nesses abalos que tecemos uma aproximação entre a Guerra do Paraguai e a Lei do Ventre Livre. Não se pretende demonstrar que o decreto de 1866 incidiu, direta e causalmente, na edição da lei emancipacionista, mas quer-se avaliar de que forma um evento específico acelerou a ordem dos acontecimentos. De que forma abalou estruturas sociais - e, por sociais, entendemos o conjunto de esferas de existência ${ }^{6}$ - e de que maneira agentes políticos foram responsáveis por esses abalos. No fundo, procura-se analisar como eventos, sujeitos e estruturas acomodaram-se, em 28 de setembro de 1871, para dar à luz a Lei do Ventre Livre.

A aproximação entre a Guerra do Paraguai e a Lei do Ventre Livre não deriva de um conforto temporal, vislumbrável no fato da lei ter surgido tão somente passado um ano e meio após o fim da conflito. Outra opção seria procurar vizinhança entre a guerra e a emancipação absoluta. Mas haveria pouca solidez em ligar a Lei Áurea, de maio de 1888, ao conflito no Prata. E isso não porque seriam frouxos os laços entre esses dois acontecimentos, mas porque a Lei do Ventre Livre pôs praticamente termo à questão servil. Em poucas palavras, a lei de 1871 decretava em seu artigo primeiro que os filhos de mulheres escravas seriam considerados livres. Nesse sentido, a escravidão estava com os dias contados, malgrado o artigo segundo, que obrigava os senhores das mães escravas a cuidar dos nascituros até os oito anos de idade, podendo, a partir daí, ora receber indenização do Estado no valor de $600 \$ 000$, ora valer-se dos serviços do menor até que este completasse vinte e um anos. Tampouco se tratava da abolição do tráfico negreiro, como fora o caso em 1850, quando da Lei Eusébio de Queiróz. Em que pese a importância dessa lei para a condução da questão servil, não era mais o ingresso de escravos no Brasil que estava em xeque, mas sua reprodutibilidade.

\section{0 que faz do evento, evento histórico?}

A julgar pela letra do decreto de 1866 ou, melhor, pelo número de libertos de guerra que combateram no Paraguai, pouco haveria de evento na participação de libertos nas fileiras do Exército brasileiro. Afinal, o decreto somente emancipava os escravos da Nação, isto é, aqueles pertencentes ao Estado. Terminaram participando libertos outros que aqueles da Nação: alguns poucos proprietários rurais e urbanos também cederam seus escravos; contudo, não mais do que 8.000 alforriados, ou menos de 10\% das tropas brasileiras, participaram do conflito ${ }^{7}$. Em que medida, portanto, poderia a participação de libertos nas tropas brasileiras constituir um evento histórico?

Compreender um evento como evento histórico - submetendo, assim, uma sucessão de acontecimentos a outra maior, que as abarca e explica -, é certamente escolha do historiador. É forma de puxar a sardinha para o lado no qual se encontra o pescador. No entanto, essa subjetividade, nas palavras de Marshall Sahlins ${ }^{8}$, é menos subjetiva se entendermos evento como mudança na estrutura, embora possa também ser produto da estrutura. Expliquemo-nos melhor. Eventos históricos diferenciam-se de eventos no sentido lexical, porque introduzem caos em estruturas, que, por definição, são representações de uma realidade social capazes de conferir 
9

SEWELL JR., William. Logics of History: Social theory and social transformation. Chicago: The University of Chicago Press, 2005. p.204.

10

FOUCAULT, Michel. Cours du 7 janvier 1976. In : Il faut defender la société, Cours au

Collège de France, 1976. Paris: Gallimard-Seuil, 1997. p.3-21.

"Não como uma decisão, como um tratado, um reino ou como uma batalha, mas como uma relação de forças que se inverte, um poder confiscado, um vocabulário retomado e revertido contra seus utilizadores, um dominio que arrefece, que se distende, que se envenena, e uma outra que entra em cena, mascarada. As forças que estão em jogo na história não obedecem nem a uma destinação nem a uma mecânica, mas ao azar da luta. Não se manifestam como formas sucessivas de uma intenção primordial; elas não tomam forma de um resultado. Aparecem sempre na álea singular do evento" (tradução livre). Cf. FOUCAULT, Michel. Nietzsche, la généalogie, I'histoire. In:_. Dits et écrits. Paris: Quatro-Gallimard, 1994. Tome I, 1954-1975, p.1004-1025

12

Há praticamente consenso entre Sérgio Buarque de Holanda, José Murilo de Carvalho e Ricardo Salles. Ver: HOLANDA, Sérgio Buarque de. História geral da civilização brasileira. 0 Brasil monárquico: do Império à República. 10a edição, Rio de Janeiro: Bertrand Brasil, 2012. Tomo II, v.7; CARVALHO, José Murilo. Cidadania no Brasil: o longo caminho. 9a edição, Rio de Janeiro: Civilização Brasileira, 2007 e SALLES, Ricardo. As águas do Niágara. 1871: crise da escravidão e 0 ocaso saquarema. In: GRINBERG, Keila; SALLES, Ricardo (orgs.). O Brasil imperial, 1870-1889. Rio de Janeiro: Civilização Brasileira, 2009. v.3. estabilidade e previsão não somente ao agente histórico, mas também ao historiador ${ }^{9}$. Estruturas, portanto, seriam tendências que provocam recorrências de um certo modelo relacional, inclusive quando os agentes dessas relações não estariam plenamente conscientes disso. É nessa inconsciência, ou consciência, que o historiador encontraria a estrutura que seu evento histórico, ou objeto de pesquisa, viria abalar. Eventos históricos, à diferença de estruturas, por violar expectativas e previsões geradas por estruturas, seriam ações, reações ou transações produzidas por agentes políticos plenamente conscientes de seus atos, embora não forçosamente dos desdobramentos desses atos.

Ocorre que, nesses termos, eventos históricos pareceriam ser momentos pontuais de tomada de consciência, subversivos de uma cadência estrutural. Ora, se assim fosse, eventos históricos seriam mais eventos do que eventos históricos. Para serem históricos, eventos devem ser entendidos como terminações de longos processos. Como saturação e, portanto, implosão de um determinado modelo de relações sociais. É precisamente o que defende Michel Foucault, ao sustentar que revoltas, decretos ou guerras não são momentos de tomada de consciência, mas resultados de práticas reais que invertem relações de força ${ }^{10}$. Processos de tomada de consciência, por serem processos, não são eventos, mas eventos históricos, definidos por Foucault:

\begin{abstract}
non une décision, un traité, un règne ou une bataille, mais un rapport de forces qui s'inverse, un pouvoir confisqué, un vocabulaire repris et retourné contre ses utilisateurs, une domination qui s'affaiblit, se détend, s'empoisonne elle-même, une autre qui fait son entrée en scène, masquée. Les forces qui sont en jeu dans I'histoire n'obéissent ni à une destination ni à une mécanique, mais bien au hasard de la lutte. Elles ne se manifestent pas comme les formes successives d'une intention primordiale; elles ne prennent pas non plus l'allure d'un résultat. Elles apparaissent toujours dans l'alea singulier de l'événement. ${ }^{11}$
\end{abstract}

Essa álea singular, ou contingência do evento histórico, é o que faz entender como artifício a dissociação feita por Dom Pedro II entre a participação de libertos no Paraguai e a questão servil. Provavelmente, naquela convocação extraordinária submetida ao Conselho de Estado, em 1866, 0 Imperador sabia que não poderia evitar a contingência de alforriar escravos para o combate no Sul, mas buscava controlá-la ao máximo, separando-a de uma questão maior, que era a abolição da escravatura. Sabia Dom Pedro, em outras palavras, que estava diante de um evento histórico, tão fecundo em resultados quanto outras razões que também contribuíram para levá-lo a incentivar Pimenta Bueno, em 1867, a apresentar no Conselho de Estado projeto de lei para alforriar o ventre das cativas. A libertação de escravos para combater no Prata entrava no caudal da agitação emancipacionista interna e externa da década de 1860. As associações de libertos (formais e informais), as sociedades emancipadoras, a imprensa, a literatura ficcional e as pressões externas davam tom à causa servil.

Por qual cargas d'água a inclusão de libertos nas fileiras do Exército poderia ser mais evento histórico do que essas outras explicações da Lei do Ventre Livre? A historiografia ressalta comumente dois grupos de razões que explicam o projeto de lei de 1867 e, por extensão, a Lei do Ventre Livre ${ }^{12}$. Entre os argumentos de ordem externa, está a carta da Junta Emancipacionista Francesa, datada de 1866 e redigida por François Guizot, Augustin Corbin, Albert de Brogitre, C. F. Audley, Eugène Junny, 
Arquivo Nacional do Rio de Janeiro. Rio de Janeiro, Brasil. Diversos, cód.953. A grande maioria desses membros da Junta Emancipacionista Francesa era também membro do Institut de France, da Academia Francesa e da Corte Penal de Paris.

14

"No momento no qual os Estados Unidos libertam seus escravos após uma longa guerra, no qual a Espanha parece tomar a via da humanidade e da justiça, Pedro II deveria dar o exemplo e libertar seus escravos da Corte e transformar os escravos em assalariados". (Tradução livre). Arquivo Nacional do Rio de Janeiro. Loc. Cit.

15

Ofícios da Legação do Brasil em Washington. Junho a novembro de 1862. Arquivo Histórico do Itamaraty. Rio de Janeiro, Brasil. 233/3/10

16

SALLES, Ricardo. Nostalgia imperial: Escravidão e formação da identidade nacional no Brasil do Segundo Reinado. 2a edição. Rio de Janeiro: Ponteio, 2013. p.131

17

A referência à Inglaterra diz respeito às pressões para a abolição do tráfico negreiro no Brasil. A referência à política do Big Stick, a seu turno, refere-se à ingerência externa entabulada pelos Estados Unidos durante a gestão Theodore Roosevelt (1901-1909).

18

Arquivo Nacional do Rio de Janeiro. Rio de Janeiro, Brasil. Diversos, cód.953.
Henry Morceau, Edouard Laboulaye e H. Walton ${ }^{13}$. Diziam os emancipacionistas franceses que,

au moment où les Etats-Unis libèrent ses esclaves après une longue guerre, où I'Espagne semble prendre la voie de I'humanité et justice, Pedro II devrait donner l'exemple et libérer les esclaves de la Cour et transformer les esclaves en salariés. ${ }^{14}$

A referência à Guerra de Secessão (1861-1865) decerto não vinha como peixe fora d'água, ou como evento distante da estrutura social brasileira. Pelo contrário, era motivo de severa atenção no Império. Em setembro de 1862, Miguel Maria Lisboa, então ministro plenipotenciário em Washington, escreveu em carta confidencial ao Marquês de Abrantes, ministro dos Negócios Estrangeiros, que caso a separação entre os Estados americanos do Sul e os do Norte viesse a perdurar,

nos dará ao menos tempo para adotar as medidas de polícia e de contemporização com o espírito do século, que nossos interesses e nossa segurança exigem, a abolição abrupta que está inaugurada pela proclamação de Lincoln, se por desgraça se realizar - se não for atalhada pela mediação europeia - nos deixará sem mais aliados naturais na América que as ilhas espanholas de Cuba e Porto Rico, expostos a sentir o peso da pressão abolicionista da Europa e dos Estados Unidos (...). ${ }^{15}$

Miguel Maria Lisboa vaticinou corretamente. A pressão europeia veio em 1866, e Pedro II não poderia desconsiderá-la com um piparote; afinal, justificava o conflito no Prata não como uma guerra contra o Paraguai, mas contra um tirano escravocrata. Em que pese a contradição entre um país que dizia levar civilização à barbárie paraguaia, valendo-se para tanto de seus escravos, não foram pressões externas que redundaram no projeto de lei de 1867 ou, ainda, na Lei do Ventre Livre ${ }^{16}$. A França de 1866 não era nenhuma Inglaterra da primeira metade do século XIX, e os Estados Unidos de então não eram os vindouros formuladores da política do Big Stick ${ }^{17}$. Embora o próprio Imperador exigira de seu punho, em 1864, ao presidente do Conselho de Ministros, Zacarias de Goés e Vasconcelos, que se pensasse o futuro da escravidão no Brasil, para que não sucedesse 0 mesmo a respeito do tráfico negreiro ${ }^{18}$ - ressaltando, assim, a humilhação que o Império sofrera -, sabia que as pressões emancipacionistas externas não seriam suficientes para abalar a ordem interna. 0 temor de Dom Pedro perante as posições externas causaria pouco tremor aos senhores de escravos. Caso quisesse realmente levar adiante a emancipação dos cativos, o Imperador teria de abrir - súbita, porém docilmente - uma brecha na estrutura escravocrata. Nada melhor do que recorrer ao artifício patriótico, em momento de guerra contra o inimigo comum. Daí o cuidado em separar a questão servil do decreto que alforriava escravos para participarem no conflito platino.

As pressões externas tiveram sua relevância, mas não foram determinantes no processo de negociação política que culminou na edição da Lei do Ventre Livre. Contribuem para explicar, mas não explicam. Entender porque são menos evento histórico do que a inclusão de emancipados nos regimentos brasileiros supõe compreender em que medida essa incorporação incidiu, ou viria a incidir, na agência de libertos, escravos, senhores e estadistas que, a seu turno, desestruturaria o regime de escravidão. Seria fomento para associações de libertos, para sociedades emancipadoras, para a imprensa e para a literatura ficcional emancipacionistas. Não que as 
19

SEWELL JR., William. Logics of History: Social theory and social transformation. Chicago: The University of Chicago Press, 2005. p.143.
Referimo-nos às atas do Conselho de Estado de 5 de novembro de 1866 (discussão relativa à inclusão de libertos nas fileiras do Exército) e às atas de 2 de abril de 1867 (discussão referente à emancipação do ventre das escravas). Para análise a respeito da posição de cada conselheiro em cada sessão ver, respectivamente, SALLES, Ricardo. A Guerra do Paraguai, a "questão servil" e a questão nacional no Brasil (1866-1871). In: PAMPLONA, Marco; STUVEN, Ana Maria (orgs.). Estado e nação no Brasil e no Chile ao longo do século XIX. Rio de Janeiro: Garamond Universitária, 2010. p.125-157; e SALLES, Ricardo. Nostalgia imperial... Op. Cit., p.131-146. pressões externas não fossem um modo de agência abolicionista. Certamente o foram, mas não suficientemente denso para abalar a estrutura escravocrata do Segundo Reinado.

\section{Estrutura escultura, agente escultor}

Longe de nós elaborar aqui uma análise sobre a estrutura social brasileira no Segundo Reinado. Seria tarefa hercúlea, a qual não pretendemos. 0 que até agora se definiu como estrutura - para começar a remediar a característica evasiva do termo - não é senão a dualidade entre o senhor e o escravo. Assim se procede porque o evento histórico analisado é a Lei do Ventre Livre. Certamente, a escravidão no Brasil imperial não se resumia ao dualismo enunciado. Existiam outras estruturas; por um lado, havia uma ordem hierárquica entre escravos: não era o mesmo ser ladino ou boçal, liberto ou de ganho, urbano ou rural; como, por outro, não havia igualdade de tratamento servil entre senhores de engenho, patrões urbanos, membros de irmandades religiosos ou da Casa Real. E isso, se falarmos apenas na ordem escravocrata. Se a essas realidades, definidas precisamente como estruturas, ordens ou sistemas, agregarmos esferas de realidade (economia, sociedade, política, cultura), temos que haveriam tantas estruturas quanto práticas relacionais fundadas na economia, na política ou na cultura. Ou ainda, tantas estruturas quanto agentes sociais. Nesse sentido, a realidade seria quase inalcançável para o historiador ou, pior, seriam tantas as figurações da realidade entre agentes históricos, que não haveria realidade histórica.

Ocorre que a comunicação, o diálogo e o entendimento entre ladinos, africanos, escravos de ganho, libertos, senhores, padres ou imperadores foram possiveis. 0 que pressupõe um apadrinhamento de uma realidade comum: no caso, a escravidão. Era essa, portanto, a estrutura que açambarcava uma prática social, desdobrável em outras ordens ou hierarquias.

Práticas sociais, assim, não são equivalentes a estruturas, porque prática implica agência, ou a capacidade dos atores políticos de mobilizar recursos materiais - e entendemos que inclusive recursos simbólicos são oriundos de recursos materiais -, para exercer algum grau de controle sobre essas mesmas práticas ${ }^{19}$. Estruturas seriam a escultura, e os agentes, os escultores. Por si só, a estrutura não constrange ou possibilita. São os agentes, e ai se incluem também os historiadores, que moldam a estrutura, em relação de força com outros agentes. Ou seja que apesar da estrutura sempre ser ponto de vista de um agente, o constrangimento derivado da existência de outros pontos de vista, que também incidem na estrutura, torna visivel o cerne da discórdia - ou concórdia. Como se a escultura estivesse no centro de um punhado de escultores. Malgrado certo alguém possa ver o dorso da escultura, e certo outro, a face, trata-se sempre do mesmo objeto, histórico, em nosso caso.

As discussões no Conselho de Estado a respeito da participação de libertos na guerra em muito ecoam aquelas entabuladas, apenas quatro meses depois, quando do projeto apresentado por Pimenta Bueno, para alforriar o ventre das cativas ${ }^{20}$. Tratava-se, no fundo, de uma análise sobre agência e estrutura escravocrata. Na sessão de 5 de novembro de 1866, a respeito da emancipação de escravos para combater no Prata, os Conselheiros foram intimados a responder a três perguntas: $1^{\text {a) }}$ Continuando a guerra, será conveniente lançar mão da alforria de escravos para aumentar o número de soldados do Exército? 2a) Que escravos serão preferiveis para o fim de que trata o primeiro quesito: os da Nação, os 
RODRIGUES, José Honório (org. e intr.). Atas do Conselho de Estado. Brasília: Senado Federal, 1973-1977. V.6, sessão de 5 de novembro de 1866. Disponivel em: <http://www.senadofederal. gov.br>. Acesso em: 26 nov. 2013.

22

Ibidem. Sessão de 2 de abril 1867.

23

Wilma P. Costa analisa, detalhadamente, a posição dos diferentes conselheiros em COSTA, Wilma Peres. A espada de Dâmocles: o Exército a Guerra do Paraguai e a crise do Império. São Paulo: Hucitec, 1996. p.245-248.
RODRIGUES, José Honório (org. e intr.). Atas do Conselho de Estado. Brasilia: Senado Federal, 1973-1977. V.6, sessão de 5 de novembro de 1866. Disponivel em: <http://www.senadofederal. gov.br>. Acesso em: 26 nov. 2013.

RODRIGUES, José Honório (org. e intr.). Loc. Cit.

RODRIGUES, José Honório (org. e intr.). Loc. Cit. das ordens religiosas, ou os dos particulares? $3^{\mathrm{a}}$ ) Como realizar essa medida?21. Mais tarde, na sessão de 1867, quando da apresentação do projeto sobre a emancipação do ventre das cativas, indagou-se aos Conselheiros: $1^{\text {a) }}$ Convém abolir diretamente a escravidão? $2^{\text {a) }}$ No caso de afirmativa: quando deve ter lugar a abolição? $3^{\text {a }}$ ) Como, com que cautelas e providências cumpre realizar essa medida?22. Embora não fossem, à primeira vista, perguntas idênticas, a resposta dos Conselheiros praticamente coincidiu nas duas sessões ${ }^{23}$. Respondeu-se como se houvessem sido indagados a respeito, primeiro, da concessão de um espaço reivindicatório aos libertos e, segundo, das possiveis rupturas na ordem social escravocrata. Agência e estrutura, portanto.

Apesar de pequenas diferenças especificas de cada conselheiro, as discussões, nessas duas sessões, dividiram-se em dois blocos: havia quem se opunha a qualquer ruptura na ordem escravocrata e quem preconizava uma emancipação gradual. Ninguém, portanto, foi implacável em defender a abolição imediata e irrestrita. Curiosamente, 0 argumento basilar contra e a favor da escravidão era o mesmo. Tratava-se de saber até que ponto ora libertar escravos para combater no Paraguai, ora alforriar o ventre das escravas seria, por contágio e incitações à insurgência, fator de distúrbio à ordem pública. Os que se colocaram contra a manutenção da escravidão absoluta alegavam serem as medidas emancipacionistas em pauta um remédio a um situação que se tornaria insustentável. Segundo esses, a aglomeração de escravos, principalmente em centros urbanos, já havia demonstrado ser um risco à ordem pública e, assim, emancipações para fins bélicos ou manumissões de nascituros viriam se não acalmar os ânimos, pelo menos demonstrar que o Estado Imperial dava ouvidos à agência dos escravos. Dizia o Conselheiro Nabuco de Araújo:

\footnotetext{
No Brasil o perigo é mais sério e mais grave; está conosco; o perigo está dentro do pais, pode surpreender-nos, afetar a ordem pública e a sociedade civil. Daí a urgência de conjurá-lo pela previsão, e pela providência; daí a necessidade de tomar a iniciativa desta grande questão; de evitar que ela se torne uma questão política e presa dos demagogos. Impedir a torrente é impossivel, dirigi-la para que não se torna fatal é de alta política. ${ }^{24}$
}

Pelo lado dos opositores a medidas emancipacionistas, usava-se o mesmo argumento, retorcendo-o no entanto. Para esses, libertar escravos para o serviço da guerra ou alforriar nascituros era avolumar os distúrbios à ordem pública, pois as medidas incitariam contágios e rebeldias. Nas palavras do Visconde de Itaboraí,

Não deixará de lembrar ainda a excitação que entre os próprios escravos produziria uma tal medida; as esperanças que ela faria nascer, o incentivo para procurarem libertar-se; e as insurreições e cenas de sangue, que daí poderiam provir, às que convém ainda acrescentar a inquietação, os sustos, e meios que a medida causaria à classe dos senhores de escravos, e principalmente aos agricultores, mais expostos do que os outros aos resultados desses tristes acontecimentos. ${ }^{25}$

\section{E completava o conselheiro Torres Homem:}

Que o Estado liberte parte dos escravos em nome da humanidade e da civilização, ou que o faça no único interesse de obter soldados, isto é indiferente; os efeitos morais são os mesmos sobre a massa geral da escravatura $[. . .]^{26}$. 
27

A expressão foi emprestada de Sidney Chalhoub. Ver: Visões da liberdade: uma história das últimas décadas da escravidão na Corte. $6^{a}$ reimpressão. São Paulo: Companhia das Letras. 2009.

28

SALLES, Ricardo. E o vale era o escravo. Vassouras, século XIX. Senhores e escravos no coração do Império. Rio de Janeiro: Civilização Brasileira, 2008. p.58.

29

KLEIN, Herbert S.; VIDAL LUNA, Francisco. Slavery in Brazil. New York: Cambridge University Press, 2010. p.74-115.

30

Ver: CHALHOUB, Sidney. Op. Cit.

31

Esse processo de antecipação de reformas foi chamado de reform-mongering por Carvalho. Ver: CARVALHO, José Murilo de. A construção da ordem: a elite imperial. Teatro de sombras: a política imperial. 6a edição, Rio de Janeiro: Civilização Brasileira, 2003. p.291-329.

32

FOUCAULT, Michel. Cours du 7 janvier 1976. In : Il faut defender la société, Cours au

Collège de France, 1976. Paris: Gallimard-Seuil, 1997. p.3-21.
No fundo, em ambos os lados, tratava-se de controlar a agência dos cativos, ora para mudar, ora para manter a estrutura escravocrata. 0 que não quer dizer que os Conselheiros de Estado tivessem todos os meios necessários para dirigir a ação dos escravos. É nessa medida que nos interessa saber se a Lei do Ventre Livre, como desdobramento de um processo que se encaminhara desde a libertação de escravos para lutar no Paraguai - ou inclusive antes -, foi arrancada ${ }^{27}$ pelos escravos ou outorgada por Conselheiros e Deputados. Um primeiro caminho seria avaliar a evolução demográfica da escravidão no Brasil, comparando-a com o preço dos cativos. Nesse sentido, verificou-se progressiva queda no número de escravos entre 1850 e 1872, embora não tenha sido esse declínio constante e retilíneo ${ }^{28}$; ao passo que, de forma reconfortante para nossa análise, o preço do escravo aumentou progressivamente nos anos de 1850 e $1860^{29}$. Resta que esses dados poucos nos informam acerca das causas da queda do número de cativos: foi um declínio demográfico natural, oriundo de uma baixa taxa de natalidade, ou um movimento crescente no número de alforrias, derivadas da agência rebelde dos cativos? Problemas de difícil resolução, aos quais a historiografia recente sobre a escravidão tem dedicado maior número de páginas.

Quer-se aqui percorrer o caminho contrário, isto é, encontrar nas palavras dos Conselheiros de Estado a agência dos escravos. Não se trata de seguir Sidney Chalhoub nos processos penais que retrataram o cativo como rebelde e, por conseguinte, como aquele que arrancou de Conselheiros e dos Deputados a Lei do Ventre Livre ${ }^{30}$; nem de enxergar no processo emancipatório uma vontade dos dirigentes imperiais de dirigir uma antecipação reformista, para controlar a inevitável abolição $0^{31}$. Enquanto aquela leitura condensa sua análise na agência escrava; esta o faz nas elites imperiais. Nosso esforço, em diálogo com essas duas visões, é o de entender o poder não como fenômeno de dominação maciço, estanque e homogêneo; mas como fluido, que circula entre agentes sociais, trazendo à tona relações de força ${ }^{32}$.

Quando Nabuco de Araújo alega urgência, para conjurar pela previsão os abalos estruturais que traria a emancipação do ventre das escravas, está dizendo que, embora a agência cativa existisse com todas as letras, a necessidade de antecipar-se a ela adviria da necessidade de controlá-la. Medidas emancipacionistas teriam tomado a forma da lei, vista a necessidade de dirigir o processo de abolição. 0 bastante para entendermos que a Lei do Ventre Livre não foi completamente um processo oriundo da agência escrava. Da mesma forma, quando o Visconde de Itaboraí sustenta a excitação que uma medida emancipacionista produziria entre os escravos, dando margem a insurreições e cenas de sangue, revela que em nada se antecipavam as antecipações à agência escrava: a rebeldia já existia, e promover reformas no sentido da emancipação, ainda que gradual, seria apenas avolumar os atos insurgentes. 0 que é o suficiente para compreendermos que a Lei do Ventre Livre não foi inteiramente um processo de antecipação à desordem pública.

Nesses termos, importam menos o número de escravos no Brasil da década de 1860, as taxas de fecundidade escrava, o preço do cativo ou o número de processos penais envolvendo dominantes e dominados. Interessam mais as possibilidades de mudança estrutural, vistas ou antevistas como possíveis realocações de recursos de poder. Convocar escravos e libertá-los para o serviço da guerra era uma, se não a possibilidade de mudança estrutural. 0 efeito patriótico ou a premência da guerra, especialmente no ano de 1866, falaria mais alto para aqueles Conselheiros que se 
0 documento está transcrito na íntegra, contendo inclusive as correções do Imperador, em LYRA, Heitor. História de Dom Pedro Il: fastígio, 1870-1880. São Paulo: Edusp; Belo Horizonte: Itatiaia, 1997. p.340-341, nota 210. negariam a permitir o ingresso de cativos nas fileiras de Caxias. Uns agiram por convicção da necessidade de engrossar as tropas brasileiras; outros, por crença nos benefícios que a medida traria para o processo emancipatório brasileiro. Enfim, alguns mais reticentes teriam de resignar-se perante a decisão do Conselho de Estado.

Tornamos então, como forma de conclusão, à questão parcialmente resolvida a respeito de ser a convocação de libertos para servir no exército $o$ evento histórico, no sentido das mudanças ocorridas na estrutura escravocrata do Império. Em resposta à carta endereçada a Dom Pedro II pela Junta de Emancipação Francesa, o conselheiro Martim Francisco respondeu que
A emancipação dos escravos, consequência necessária da abolição do tráfico, é somente uma questão de forma e de oportunidade. Quando as penosas circunstâncias em que se acha o país o consentirem, o Governo brasileiro considerará como objeto de primeira importância a realização do que o espírito do cristianismo desde há muito reclama do mundo civilizado. ${ }^{33}$

As penosas circunstâncias às quais se referia o conselheiro Martim Francisco nada mais eram do que a Guerra do Paraguai. Não sem os cuidados de Dom Pedro II, respondia-se à Junta alegando que trazer à baila uma lei emancipacionista da envergadura da vindoura Lei do Ventre Livre seria excitar a discórdia entre os estadistas do Império, em momento no qual a paz política era mais do que necessária para levar a termo o conflito contra Solano López. Haveria, no entanto, uma saída mais amistosa, ou pelo menos mais afeita ao consenso patriótico. A emancipação, que Martim Francisco atrelava à abolição do tráfico, em 1850, tomou forma com a oportunidade que trouxe a proposta feita por Dom Pedro ao ConseIho de Estado em novembro de 1866, pouco depois da resposta imperial à Junta de Emancipação Francesa: devia-se libertar escravos para o serviço da guerra?

Não por fruto de pressões externas, embora contassem para a imagem que Dom Pedro queria do Brasil, mas por circunstâncias bélicas, editou-se o decreto de 1866. Pouco depois, conforme suspeitavam os Conselheiros na sessão de 6 de novembro de 1866, a questão emancipacionista tomou a frente no Conselho de Estado. E isso, apesar das penosas circunstâncias nas quais se encontrava o Brasil. Em 1867, o Conselho aprovou um arremedo de projeto, cuja autoria de Nabuco de Araújo pouco alterava a versão original de Pimenta Bueno. Em 28 de setembro de 1871, a proposta de Nabuco de Araújo foi retomada, ajustando-a aos sabores dos Deputados, e o ventre das cativas foi libertado.

Foi a convocação de libertos para o serviço de guerra, portanto, o nódulo da questão servil. As pressões externas poderiam pesar sobre 0 Imperador, mas não foram suficientes para convencer as facções escravocratas brasileiras a abrir mão de seus cativos. Tampouco puderam resistir os Conselheiros conservadores ortodoxos, mais vinculados às vozes dessas facções, às urgências da guerra. A participação desses libertos de guerra era oportunidade singular para levar adiante o processo emancipacionista, caro ao Imperador. Não por acaso, essa convocação veio sob forma de decreto, e não de lei: a premência da guerra não toleraria os desentendimentos e o tempo que a Câmara demandaria.

Outro porquê da Lei do Ventre Livre comumente apontado pela historiografia diz respeito ao sequestro da agenda liberal promovido pelo presi- 
É este o segundo bloco de razões que comumente foram assinalados como causa da Lei do Ventre Livre. Ver: HOLANDA, Sérgio Buarque de. Op. Cit.; SALLES, Ricardo. As águas do Niágara..., Op. Cit.

35

SOARES, Carlos Eugênio Líbano. A negregada instituição: os capoeiras no Rio de Janeiro. Rio de Janeiro: Biblioteca Carioca, 1998.

36

BASILE, Marcello Otávio. Consolidação e crise do Império. In: LINHARES, Maria Yedda (org.). História geral do Brasil. 9a edição, Rio de Janeiro: Campus, 2000. p.271.

Recebido para publicação em 01 de dezembro de 2013

Aprovado em 03 de março de 2015 dente do Conselho responsável pela sanção da lei de 1871, o conservador José Maria da Silva Paranhos, então Visconde do Rio Branco ${ }^{34}$. Teria sido a lei emancipacionista uma astúcia política do gabinete conservador, para esvaziar o teor das reivindicações liberais, tomando-as para si? 0 problemático dessa leitura é que desconsidera não somente a trajetória do próprio Paranhos ao longo das discussões entabulados desde 1866 a respeito da abolição, como também, as razões da queda do gabinete Pimenta Bueno, então visconde de São Vicente, que precedeu o de Paranhos. Embora Rio Branco tenha mostrando-se contrário, em 1866, à alforria de escravos para combater no Paraguai, sua nomeação como ministro plenipotenciário, enviado a Assunção em 1869, o obrigou a defrontar-se com o peso da opinião estrangeira: como poderia um Exército composto de libertos de guerra dizer-se portador de valores civilizatórios à nação vencida? E ainda, como poderia esse mesmo Exército impor ao Paraguai a abolição da escravidão?

Quando dos debates acerca da natureza da vindoura Lei do Ventre Livre, pouco antes do 28 de setembro de 1871, Rio Branco enfatizava a seus colegas do partido Conservador que a questão emancipacionista não era um problema para o futuro. A agência de escravos e de libertos, especialmente os veteranos da Guerra do Paraguai, fazia-se sentir na Corte ${ }^{35}$. 0 problema era imediato, dizia Paranhos, quase que retomando as discussões daqueles que em 1866 se colocaram a favor do decreto que libertou escravos para o conflito externo. Pouco tinha a ver, portanto, a posição de Paranhos com um eventual sequestro da agenda liberal, embora esse esvaziamento do partido de oposição pudesse trazer benefícios políticos aos conservadores. A indicação do Visconde do Rio Branco para a presidência do Conselho de Ministros, em março de 1871, vinha como cartada final de Dom Pedro, na medida em que o gabinete anterior, o de Pimenta Bueno, que durou apenas seis meses, havia caído precisamente devido a sua incapacidade de congregar forças políticas necessárias para sancionar a Lei do Ventre Livre ${ }^{36}$. E não somente isso: o ministério predecessor também havia caído pela relutância de seu presidente, o Visconde de Itaboraí, em encaminhar a liberdade dos nascituros. A ideia de Pimenta Bueno não era sequestrar a agenda liberal, mas convencer o partido conservador a topar a aprovação da lei. Somente o Visconde do Rio Branco, na visão do Imperador, pelo prestigio angariado no Paraguai e, quem sabe, por ser um liberal reformado e de fraque diplomático, poderia conciliar as vozes dissonantes, tanto do partido Conservador, quanto do Liberal. Seria uma espécie de Honório Hermeto Carneiro Leão après-coup, que fora presidente do Ministério da Conciliação, entre 1853 a 1856.

Foi a participação de libertos na Guerra do Paraguai o evento histórico que acelerou a ordem dos acontecimentos. Como toda interpretação, carrega essa uma dose de subjetividade. Mas essa subjetividade menos subjetividade é, como antes dissemos, se entendermos eventos históricos como mudanças estruturais. Práticas que garantem a permanência de estruturas são históricas também; contudo, mais evento histórico é aquela prática que aquilata uma descontinuidade na estrutura, uma mudança. Isto é, aquela que foge à ordem estrutural. Poder-se-ia ainda dizer que a ordem estrutural é uma escolha e, portanto, que o evento histórico é uma objetividade que se dá dentro de uma subjetividade. Ocorre que os eventos têm sua concretude, e dificilmente poderíamos pensar que a estrutura era a Lei do Ventre Livre; e a descontinuidade, a escravidão. A realidade comum não era a participação de libertos na Guerra do Paraguai. 